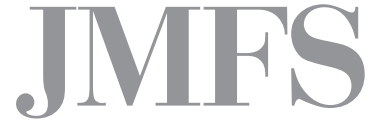

Journal of Management and Financial Sciences
Volume XIII

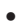

Issue 40 (March 2020)

pp. $9-20$

SGH Warsaw School of Economics

Collegium of Management and Finance

Olga Mikołajczyk

Institute of Finance

Collegium of Management and Finance

SGH Warsaw School of Economics

ORCID: 0000-0001-8878-3596

Bartosz Owedyk

Institute of Finance

Collegium of Management and Finance

SGH Warsaw School of Economics

\title{
Creating value in investments with the use of private equity funds
}

\begin{abstract}
The influence of the private equity sector on the contemporary economy is quite significant. This is why the present paper attempts to examine mechanisms private equity investors apply in order to increase the value of their investments. The literature review has identified the most fundamental elements of creating value on the basis of empirical, academic studies that verified hypotheses regarding the influence of particular mechanisms on the process of value creation in private equity investments. This paper is divided into five parts that describe the elements of the investment process, research into value creation, financial arbitration, as well as direct and indirect mechanisms of creating investment value. The paper is mainly based on the review of foreign-language literature.
\end{abstract}

Keywords: value creation, private equity, return on investment, investment process JEL Classification Code: G32 


\section{Introduction}

Private equity investments are one of the most important elements of the global capital market. At their core lies investing capital in securities of private companies in order to obtain high return on investment. The influence of the private equity sector on the contemporary economy is significant and especially strong in business lines characterized by high growth dynamics. This is why it is of interest here to examine the mechanisms private equity investors use to effect growth in the value of their investments.

Due to the non-public nature of the investments, analysis of the way private equity funds operate presents quite a challenge to practitioners and academics alike. Over the last few decades, a number of empirical studies verifying hypotheses about the impact of specific mechanisms on the process of creating value in private equity investments have been conducted. These studies have contributed valuable information and identified key factors of value creation. This, in turn, facilitated formulation of a complex outline of the analysis of the value increase process applied by private equity funds, hence making it possible to conduct structured analysis of individual investments.

The purpose of this paper is to identify the most important factors that influence the process of creating value in private equity investments and to present an academic approach to analyzing this process on the basis of research conducted by scholars of foreign academic institutions.

\section{Elements of an investment process}

Conducting a fund's investment process is a fundamental task of a private equity manager. A team of a particular private equity company's employees is usually responsible for initiating a new investment, managing and monitoring its course, as well as conducting the disinvestment process. Ordinarily, initiating a new investment and other key investment decisions require approval of an investment committee, which acts as a parent organizational unit that manages investment activities of a private equity fund.

The investment process begins by attracting potential projects, followed by an initial analysis of adopted investment criteria. Typically, the process of initial selection focuses on the vision for further company growth, market prospects, the company's financial situation, competencies of its managing board, as well as preliminary valuation of the investment. Multiple valuation methods become useful in the process of estimating the value of the shares subject to potential investment, due to the diverse nature of the investment and the availability of information. Multipliers methods, historical transaction prices based on Enterprise Value, as well as the revenue method are among the most common of those. When initial screening turns out to be positive, the second phase begins, aiming at creating a complex analysis that determines the 
current activities of the company, potential strategy of its development, as well as the range of the projected return on investment. Simultaneously, negotiations with owners are taking place with regard to the initial share purchase price. Phase two ends with a decision by the investment committee as to whether to continue the work or suspend the project. When the decision is positive, the fund submits to the owners of the analyzed corporation a proposal that contains an initial share purchase offer and conditions of the potential transaction, in form of a term sheet or non-binding offer for acceptance [Wrzesiński, 2006, pp. 115-123; Szlęzak-Matusewicz, Felis, 2014, pp. 51-52; Sobańska-Helman, Sieradzan, 2013, pp. 86-103]. Acceptance of initial conditions by company owners initiates detailed assessment of the company in form of the due diligence process - a complex analysis that facilitates assessment of the company's potential, estimation of the value of purchased shares, as well as identification of potential transactional and business risk. The process encompasses many key areas of the company's operations. Usually, the following aspects undergo analysis: commercial, financial, tax, legal, and environmental. Simultaneously, further negotiations with company owners are conducted with respect to the transaction, and a detailed business plan for the investment period is formulated together with the company's managing board. Results of the due diligence process, findings with respect to the final valuation and the business plan, as well as complex analyses of the projected return on investment are presented to the investment committee for acceptance [Sobańska-Helman, Sieradzan, 2013, pp. 50-61, 100-103; Błach, pp. 132-133].

The final acceptance of the investment project by the committee results in the private equity fund concluding agreements that determine the purchase of shares and outline cooperation with the company's managing board.

At the time of the acquisition of control of the company's portfolio, the investment period begins. It is the most important phase of the investment process, because it is responsible for building the company's value, which will be described further in this paper.

During the investment process, managers regularly monitor the projected value of the company and the degree of realization of the business plan. When the company's value and realization of the investment assumptions are optimal for maximum profit, or when the timing of the fund renders investment exit, the process of disinvestment is conducted. Private equity managers have relatively numerous options for withdrawing capital from the company's portfolio. Some of them include trade sale, sale of the company's shares through the public market, secondary buyout, purchase of the fund's shares by the company's current managing board ( $\mathrm{MBO}$ ), or liquidation or sale of company assets. According to the data from Invest Europe, an organization of leading European funds, between 2014 and 2018, trade sale was the most common method of exiting investment in Europe both with respect to value and transaction volume. In recent years, secondary buyout has been a more and more frequent method of disinvestment. Exiting the investment by means of selling shares through the public market has successfully been conducted in many private equity investments, yet the value of such transactions has consistently been decreasing since 2015 [Zimny, 2013, pp. 194-202]. 


\section{Research related to the process of value creation}

The process of value creation in private equity investments is a derivative of many factors directly related to the investment itself and its environment. Extensive empirical research into private equity investment began in the 1980s, during intensive development of venture capital funds on the US market [Loos, 2006, pp. 9-12]. Over the decades, the process of creating the value of private equity investments has been subject of many academic publications and commercial analyses. Due to the many facets of this research problem, it became a subject of study not only in finance, but also strategic management, entrepreneurship, and behavioural economics [Wright, Coyne, 1991, pp. 15-18].

Michael C. Jensen and William H. Meckling were two of the pioneers of empirical research. The authors identified factors that influence key value creation factors in investments. In their 1976 publication, they analyzed the impact of corporate ownership structure on conflicts resulting from the agency theory describing issues and potential costs associated with natural incompatibility of goals and motivation of the management and owners of the company. Results of this study show that in the case of acquisition of the control of the company by a group consisting of a professional investor and management, issues arising from the agency theory are almost completely mitigated thanks to the potential benefits for the board resulting from capital commitment. Hence, this publication proves that effective use of tools for motivating managers through participation in the growth of enterprise value is one of the key components of the process of value creation [Jensen, Meckling, 1976, pp. 68-71].

In the study, published in 1989, S. Kaplan presented results of a multi-layered analysis of the activities of 48 companies controlled by private equity funds. Empirical results showed a statistically significant relationship between the process of value creation of a portfolio company and an increase of operational profit (EBIT) as well as an increase of the nominal value of operating cash flows generated by the company during the investment period [Kaplan 1989, p. 24]. The above results were complemented by an analysis of the financial results of 58 portfolio companies of private equity funds conducted by Smith in 1990. The study confirms the statistically significant improvement in the operational effectiveness of the company (expressed as a ratio of EBITDA to fixed assets) as well as optimization of the working capital after acquiring control of the company by the private equity as a result of an $\mathrm{MBO}$ transaction. The author concludes that direct involvement of the managing board as company shareholders and professionalization of corporate governance both become direct factors that qualify improvement of the effectiveness of portfolio company operations [Smith, 1990, pp. 150-164].

V. Acharya's (2008) edited publication presents an interesting research approach to the value creation process by private equity funds. The authors analyzed over 100 Western European private equity investments characterized by high rates of return relative to the market average. Results of the analysis showed that above-average return on investment is usually directly due to the simultaneous increase in enterprise scale, improvement of the margins, as 
well as price arbitrage during the disinvestment process. Aside from factors that are purely related to the development of the portfolio company, the authors also list human capital and experience of the individuals managing the private equity fund as highly significant indirect factors in the value creation process [Acharya, Viral, Gottschalg, Hahn, Kehoe, 2009, pp. 2-8].

Results of extensive research into private equity investments made it possible to identify key value creation factors and to consistently classify them. One of the most important papers that summarized $20+$ years of academic research and analysis of value sources in private equity investments comes from O.F. Gottschalg and A. Berg. Titled Understanding value generation in buyouts, this paper presents conclusions that stem primarily from an overview of empirical studies into European and American private equity markets, and identifies three main levers of buyout value generation [Berg, Gottschalg, 2005, pp. 11-13]:

- Value creation levers: the process of building value may take place during each of the three investment stages: acquisition, holding period, and disinvestment.

- Sources of value creation: the process of building private equity investment value can be brought down to maximizing the value of shares or stocks of the portfolio company. Consequently, when basing on Enterprise Value, the process of value creation may be presented as a result of four factors constituting the following equation [Ross, Westerfield, Jaffe, 2016, pp. 273-274]:

$$
\text { Value of shares }=\frac{E V}{E B I T D A} \text { multiplier } * \text { Revenue } * \text { EBITDA margin }- \text { Net debt }
$$

- Value creation determinants: the authors identified two types of investment value creation factors: intrinsic and extrinsic. When it comes to intrinsic value, it is all about value creation on the basis of optimizing internal processes within the company, such as introduction of efficient cost control; no significant flow of knowledge takes place between private equity investors and the company. On the other hand, with regard to extrinsic value, it is important to pay attention to building the value of investment with a substantial flow of knowledge and the know-how between the portfolio company and the private equity fund by means of, for example, supporting client acquisition by the portfolio company thanks to the relations and experience of private equity fund managers.

The concept proposed by A. Berg and O. Gottschalg became a basis for subsequent empirical studies, including an analysis of 3,000 private equity investments in form of leveraged buyouts between 1973 and 2003, published by N. Loos under the title Value creation in leveraged buyouts. Analysis of factors driving private equity investment performance. Through this analysis, the author confirmed that improvement of operational effectiveness is one of the key factors that create the investment value. Moreover, results of this study showed that both the use of debt in investment structure and extensive incentive programmes for the management of a portfolio company allow for a significant reduction of the agency problem, which occurs in the case of conflicting objectives and aspirations of the managerial staff and the entity that owns the company [Loos, op.cit., pp. 392-415]. 


\section{Financial arbitration as a value growth mechanism}

The following are two fundamental mechanisms responsible for increasing value in private equity investments [Berg, Gottschalg, op.cit., pp. 11-13]:

- value capturing, meaning increase in the value of portfolio company stock/shares as a result of changes in the assumptions used in the valuation process; most frequently, this refers to changes in the market multipliers of comparable transactions, especially the EV/ EBITDA multiplier used for valuation of shares/stocks;

- value creation or increase in the value of shares/stocks of the portfolio company as a result of changes in financial results and capital structure of the company. Value creation may take place by means of mechanisms that directly or indirectly influence the company's results and its financial standing.

Financial arbitration in the context of private equity investment includes increased investment value resulting from changes in the parameters that underlie the valuation of shares between investment and disinvestment. Due to the long investment horizon and usually a complex and heterogeneous process of the subsequent sale of the acquired shares or stocks, arbitration in private equity investments does not occur in a purely economic sense. Obtaining return on investment by a private equity fund as a result of arbitration is subject to considerable uncertainty; at the moment of initiating investment, even when valuation is significantly lower than what market conditions indicate, it is impossible to state whether financial arbitration will be implemented during the disinvestment process, because market indicators used in the process of valuation change over time [Hannus, 2015, pp. 56-57; Samuelson, Nordhaus, 2012, pp. 467-469]. Basing on empirical studies [Berg, Gottschalg, op.cit., pp. 8-10], one may state that there are many key factors affecting the valuation obtained in transactions of private equity funds. One of those factors is an increase in the value of market multipliers of comparable companies, usually based on the ratio of enterprise value and EBITDA or revenue. Practitioners call the investment strategy that assumes obtainment of a significantly higher valuation multiplier during disinvestment multiple riding. Conviction that the future increase in the average valuation ratios in the industry, resulting from e.g. change in the business cycle or technological development, forms the basis of its application.

Use of information unavailable to other transaction participants, obtained for example thanks to excellent knowledge of the given industry, may form another factor. Empirical experience confirms that specialized private equity funds use the obtained intellectual capital, a wide network of contacts, and vast investment experience to build competitive advantage over other investors. This primarily applies to the possibility of gaining access to most significant information and individuals, as well as to the speed of handling the potential transaction [Fox, Marcus, 1992, pp. 62-80].

Valuation may also be influenced by the use of internal information about the company, unavailable to other transaction participants, such as close relations with the managing board 
of the company during early stages of the transaction process. Due to progressive professionalization of transactional processes and increasing competition between investors, gaining access to internal information is becoming more difficult and less common in market practice [Leleux, Swaay, Megally, 2015, pp. 64, 74-78].

Experience in carrying out and structuring M\&A transactions is another important factor that influences valuation. Access to customized transactional processes, in which it is possible to obtain more favorable valuation metrics from the perspective of the buyer, in comparison with the standard auction process, is one of the important aspects of an investment's value creation via financial arbitration [Wright, Robbie, 1996, pp. 695-700]. The other strategy, based on financial arbitration, employed by private equity funds is the so-called asset stripping, otherwise known as purchase of a diversified company with a discount due to the holding and business structure and then realization of profit through the sale of individual components of the conglomerate in separate transactions, thereby achieving higher valuation void of the discount.

\section{Direct forms of value creation}

The process of direct value creation in an investment is based on an increase in the value of the portfolio company's shares/stocks as a result of occurrence of mechanisms that directly impact the company's financial results and its capital structure. In the context of private equity investment, financial engineering is one of the direct ways of creating value. It includes optimization of the company's capital structure in order to minimize capital costs and to minimize the real rate of taxation. The above elements usually play the most significant role in the case of a leveraged buyout (LBO) [Baker, Filbeck, Kiymaz, 2016, pp. 346-356]. Indebtedness introduced to the company as a result of the LBO decreases the real rate of taxation through the tax shield effect. It is important to note that increasing the rate of a company's indebtedness is associated with a relatively high cost of incurred liabilities. Empirical studies show that in most cases of LBO characterized by relatively high value of debt financing, the positive effect of the tax shield is offset by the additional costs and material risks that arise from high company indebtedness [Loos, op.cit., pp. 26-28].

The optimization of capital structure may also include obtainment of external funding by the portfolio company for the need of working capital or for an investment programme. In this case, the private equity fund may indirectly bring about very high value, for example by means of supporting the managing board of the portfolio company in the process of negotiating the terms of financing with financial institutions.

Effective management of the operational activities of a portfolio company is one of the key components of the process of an investment's value creation [Caputa, Paździor, Krawczyk-Sokołowska, pp. 19-20]. The managing board of a given company is directly responsible for its operational activities. When exercising control over the portfolio company, the private 
equity fund usually supports the company's managing board during the process of identifying domains that require improvement of their operational effectiveness, as well as during the process of implementing solutions that aim at improving the company's overall operations. In the case of private equity funds that specialize only in the operations of a particular business line or economic sector, the fund's operational engagement is usually greater due to the fact that it possesses knowledge and experience acquired in the previous investment processes.

A number of factors can be identified as the most important elements of improving a company's operational effectiveness [Berg, Gottschalg, op.cit., pp. 14-19]. Two of the most fundamental of those are cost optimization as well as improvement of the company's margins. Much empirical research confirms a significant improvement in a company's operating profitability during private equity fund investment. However, achievement of high nominal value of cost savings is not a key factor here; it is maintenance of cost structure that renders it possible to generate the anticipated profit levels as well as further development of the company's operations. During the private equity fund's investment period, the value of cost items that are significant for further development of the portfolio company, such as research and development or marketing, usually increases in relation to the company's income.

Working capital optimization is the next element that influences operational effectiveness. In most cases of private equity funds' portfolio companies, the optimization is achieved by means of increasing effectiveness and professionalism of managing trade receivables or inventories while maintaining competitiveness of the company's business model [Easterwood, Seth, Singer, 1989, pp. 30-43].

Improvement in the quality of operational management is not void of significance, either [Leeds, Satyamurthy, 2015, pp. 80-92]. Ordinarily, it takes place during an early phase of investment by means of identifying weak links in managerial structures of the company and then by introducing corrective measures.

When attempting to improve their operational effectiveness, portfolio companies may rely on the fund's support resulting from synergy in many areas of operations: exchange of experience between individual companies is a good example of a benefit in this regard. Fund managers who service individual portfolio companies may exchange knowledge of business matters, markets, or accounting policies implemented by other companies that operate in a similar segment.

Paying attention to the aspect of strategic management is another direct value creation mechanism. On the stage of investment preparation and analysis it is a standard to adopt a certain investment approach as well as main assumptions with regard to company development during the course of the investment, along with assessing the influence they exert on projected financial results of the company. These arrangements usually arise in the course of cooperation between the private equity fund's investment team and the board of the potential portfolio company. Therefore, the beginning of the company's development strategy is heralded before the period of investment, which allows for rapid implementation of the main goals shortly after taking control of the company. 
The private equity fund normally supervises the company at the level of the managing board and does not get involved in its operational management. The strategy formulated for the duration of the investment is usually characterized by clearly set goals that are expected to influence the company's financial results, thanks to which it is possible to verify the strategy's implementation from the level of the board of directors.

A clear and easily verifiable strategy leads to many beneficial changes in the portfolio companies of private equity funds. Some of such changes are exemplified by improvements in operational effectiveness of main business lines, simplification of a business model, and development by means of innovation and acquisitions [Berg, Gottschalg, op.cit., pp. 20-21].

\section{Indirect forms of value creation}

From the perspective of the agency theory, the structure and type of the controlling entity is one of the most significant factors that influence cost reduction. In the case of a company buyout by a private equity fund, either from individual private owners or from another company, we observe significant changes in the areas directly related to the relations between the managing board and company owners [Kaplan, op.cit., p. 217].

There are three main factors that could significantly mitigate the differences between motivations and goals of the managing board and the professional financial investor (i.e. private equity fund) that controls the company [Loos, op.cit., pp. 20-21]. The first of these factors is exercising smooth and effective supervision over portfolio companies; this is in fact a fundamental duty of the private equity fund. This is due not only to the obligations of the fund with respect to its capital donors, but also to the motivation to maximize the return on a given investment.

The next factor is the introduction of motivational programmes for the managing board, based on direct participation in the success of the investment. At the moment of initiating the investment by a private equity fund, members of a company's managing board are encouraged to invest their own funds in purchasing or further increasing minority stock in the company. Ratchet instruments, otherwise known as deferred compensation based on managerial options and share subscription, guarantees appropriated to members of managing boards in the case of achieving anticipated financial parameters of the company, are also elements of motivating the managing boards of portfolio companies of private equity funds. The above mechanism enables a significant increase in benefits for managers upon exceeding a predetermined return on investment, hence standardizing goals and motivations of the investor and the company's managing board [Caselli, Garcia-Appendini, 2008, pp. 27-29].

A significant share of foreign capital in the form of financial obligations in the capital structure of the company's portfolio has a major impact on how the company is managed. High indebtedness is inextricably linked with the risk of liquidity loss, so the board is usually committed to fast repayment of financial liabilities. Consequently, this means that any 
additional cash flow will not be made available to the managing board but will be set aside for faster repayment of debt. This mechanism facilitates limiting funds available for discretionary decisions of the board, thanks to which problems arising from the impact of the agency theory are reduced [Berg, Gottschalg, op.cit., pp. 20-23]. Due to the fact that the loss of liquidity may potentially bring about legal consequences, the managing board is motivated to mitigate the risk of the company's bankruptcy, thanks to which it may potentially more effectively manage the company and make more responsible decisions regarding expenditure [Cotter, Peck, 2001, pp. 128-137, 145].

In private equity investments, relations of a fund's managers and managing boards of portfolio companies frequently go beyond the sphere of corporate governance. Usually, experienced private equity experts advise and support their portfolio company's management by offering very good relations with financial institutions as well as the know-how resulting from previous investment processes. Active support by the private equity fund in promoting entrepreneurship and innovation in their portfolio companies' operational activities is another significant aspect. Support in obtaining financing for business development on the stage of further investment rounds is also important.

\section{Summary}

This paper attempted to answer the question of what mechanisms influence the value creation process in private equity investments. Empirical studies devoted to value creation reveal various key components of the value creation process. They can be divided into direct and indirect mechanisms as well as financial arbitration, while the value creation leverage itself can be broken down to three main spheres: phases, sources, and determinants of value creation. This paper showed key mechanisms based mainly on foreign literature and examples.

An academic approach to analyzing the value creation process may warrant further research into the private equity sector. It would be interesting to examine companies operating on the Polish market, by sectors, to determine whether the current value creation factors in the global capital market coincide with the factors occurring in investments made in the Polish market.

\section{References}

\section{Compact publications}

1. Baker, H.K., Filbeck, G., Kiymaz, H. (Eds) (2016). Private Equity. Opportunities and Risks. New York: Oxford University Press.

2. Błach, J. (2018). Innowacje finansowe w przedsiębiorstwie. Warszawa: Wydawnictwo C.H. Beck.

3. Caputa, W., Paździor, A., Krawczyk-Sokołowska, I. (2017). Wartość klienta w perspektywie wiedzy i rozwoju przedsiębiorstwa. Warszawa: Texter. 
4. Caselli, S., Garcia-Appendini, E. (2008). Explaining returns in private equity investments. Mediolan: Universitá Commerciale L. Bocconi.

5. Leleux, B., Swaay, H., Megally, E. (2015). Private equity 4.0. Hoboken: Willey.

6. Leeds, R., Satyamurthy, N. (2015). Private Equity Investing in Emerging Markets. Opportunities for Value Creation. New York: Palgrave Macmillan.

7. Loos, N. (2006). Value creation in leveraged buyouts. Wiesbaden: Deutscher Universitaets-Verlag.

8. Ross, S., Westerfield, R., Jaffe, J. (2016). Corporate finance. New York: McGraw-Hill Education.

9. Samuelson, P., Nordhaus, W.D. (2012). Ekonomia. Poznań: Dom Wydawniczy Rebis.

10. Sobańska-Helman, K., Sieradzan, P. (2013). Inwestycje private equity/venture capital. Warszawa: Wydawnictwo Key Text.

11. Szlęzak-Matusewicz, J., Felis, P. (Eds.) (2014). Finansowanie przedsiębiorstwa. Ujęcie teoretyczno-praktyczne. Warszawa: Oficyna a Wolters Kluwer business.

12. Wright, M., Coyne, J. (1991). UK Management Buy-Outs: Debt, Equity and Agency Cost Implications. London: Croom-Helm.

13. Wrzesiński, M. (2006). Kapitał podwyższonego ryzyka. Proces inwestycyjny i efektywność. Warszawa: Szkoła Główna Handlowa w Warszawie - Oficyna Wydawnicza.

14. Zimny, A. (2013). Decyzje na rynkach Venture Capital/private equity. Łódź: Wydawnictwo Uniwersytetu Łódzkiego.

\section{Papers and studies}

1. Acharya, A., Viral, V., Gottschalg, O.F., Hahn, M., Kehoe, C. (2009). Corporate Governance and Value Creation: Evidence from private equity. Finance Working Papers, No. 232, European Corporate Governance Institute (ECGI).

2. Berg, A., Gottschalg, O. (2005). Understanding value generation in buyouts. Journal of Restructuring Finance, Vol. 2, No. 1.

3. Cotter, J., Peck, S. (2001). The structure of debt and active equity investors: the case of buyout specialists. Journal of Financial Economics, No. 59.

4. Easterwood, J., Seth, A., Singer, R. (1989). The impact of leveraged buyouts on strategic direction. California Management Review, No. 32.

5. Fox, I., Marcus, A. (1992). The causes and consequences of leveraged management buyouts. Academy of Management Review, No. 17(1).

6. Hannus, S. (2015). Value Creation in private equity: A Case Study of Outperforming Buyouts in the Nordic Countries. Tampere University of Technology - Publications, Vol. 1328.

7. Jensen, M., Meckling, W. (1976). Theory of the Firm: Managerial Behavior Agency Costs and Ownership Structure. Journal of Financial Economics, No. 4.

8. Kaplan, S. (1989). The effects of management buyouts on operating performance and value. Journal of Financial Economics, No. 24.

9. Smith, A. (1990). Corporate ownership structure and performance: The case of management buy-outs. Journal of Financial Economics, No. 27.

10. Wright, M., Robbie, K. (1996). The investor-led buy-out: a new strategic option. Long Range Planning. The Academy of Management Annals, Vol. 29, No. 5. 